\title{
Handbook of Florida Water Regulation: Florida Everglades Forever Act $^{1}$
}

\author{
Michael T. Olexa, Luke D'Isernia, Laura Minton, Dulcy Miller, and Sarah Corbett ${ }^{2}$
}

\section{Preface}

This handbook is designed to provide an accurate, current, and authoritative summary of the principle Federal and Florida laws that directly or indirectly relate to agriculture. This handbook should provide a basic overview of the many rights and responsibilities that farmers and farmland owners have under both Federal and Florida laws as well as the appropriate contact information to obtain more detailed information. However, the reader should be aware that because the laws, administrative rulings, and court decisions on which this handbook is based are subject to constant revision, portions of this publication could become outdated at anytime.

Several details of cited laws are also left out due to space limitations.

This handbook is distributed with the understanding that the authors are not engaged in rendering legal or other professional advice, and the information contained herein should not be regarded as a substitute for professional advice. This handbook is not all inclusive in providing information to achieve compliance with the Federal and Florida laws and regulations governing water protection. For these reasons, the use of these materials by any person constitutes an agreement to hold harmless the authors, the Florida Cooperative Extension Service, the Institute of Food and Agricultural Sciences, and the University of Florida for any liability claims, damages, or expenses that may be incurred by any person as a result of reference to or reliance on the information contained in this handbook.

\section{Overview}

The Florida Everglades Forever Act (FEFA) outlines the state government's latest commitment to restore the Everglades Ecosystem, as a contribution to and in cooperation with the federal government's overall multi-billion dollar, multi-decade,

Comprehensive Everglades Restoration Program (CERP) to restore the Florida Everglades Ecosystem. The primary goals of FEFA are to improve water quality by reducing the level of phosphorus that enters the Everglades Ecosystem; to increase the quantity of water in the Everglades by restoring the

1. This is EDIS document FE609, a publication of the Food and Resource Economics Department, Florida Cooperative Extension Service, Institute of Food and Agricultural Sciences, University of Florida, Gainesville, FL. Published December 2005. Please visit the EDIS website at http://edis.ifas.ufl.edu.

2. Michael T. Olexa, Professor, Food and Resource Economics Department, Florida Cooperative Extension Service, Institute of Food and Agricultural Sciences, University of Florida, Gainesville, FL; Director, Agricultural Law Center, University of Florida, Gainesville, FL; and Chair, Agricultural Law Committee of The Florida Bar. Luke D'Isernia, former student (graduated cum laude in 2005), Levin College of Law, University of Florida, Gainesville, FL. Laura Minton, Attorney, Dean, Mead, Egerton, Bloodworth, Capouano, and Bozarth, Orlando, FL. Dulcy Miller, attorney, Foley and Lardner, LLP, Orlando, FL. Sarah Corbett, Attorney, Florida Second District Court of Appeal, Lakeland, FL.

The Institute of Food and Agricultural Sciences (IFAS) is an Equal Opportunity Institution authorized to provide research, educational information and other services only to individuals and institutions that function with non-discrimination with respect to race, creed, color, religion, age, disability, sex, sexual orientation, marital status, national origin, political opinions or affiliations. U.S. Department of Agriculture, Cooperative Extension Service, University of Florida, IFAS, Florida A. \& M. University Cooperative Extension Program, and Boards of County Commissioners Cooperating. Larry Arrington, Dean 
hydrology of the ecosystem; and to restore and protect the native plants and animals of the Everglades by stemming the invasion of exotic species of plants and animals into the ecosystem, all while maintaining the standard of living in South Florida. The secondary goals of FEFA include water resource development and supply, increased public access, public lands management and maintenance, and increased protection of land by acquisition of conservation easements. Most of these goals are obtained by state acquisition of the subject land.

Non-point source pollution, especially from agricultural non-point sources, is a major contributor of the phosphorus contamination of the Everglades, and is addressed in FEFA with the use of best management practices (BMP) and stormwater treatment areas (STA).

\section{Who Enforces the FEFA?}

Under FEFA both the Department of Environmental Protection (DEP) and the South Florida Water Management District (SFWMD) are given enforcement power and duties in areas that include the Everglades Construction Project, water supply improvement and restoration, the Everglades research and monitoring program, evaluation of water quality standards, implementation of best management practices against phosphorus runoff in the Everglades Agricultural Area (EAA); the monitoring and controlling of exotic species; and the assessing and collecting of taxes and special assessments. A major goal is to decrease the levels of phosphorus in the Everglades to acceptable levels which will improve the overall health of the Everglades Ecosystem and surrounding vicinities.

\section{What Are the Duties of DEP and SFWMD under FEFA?}

Under FEFA, the SFWMD is charged with implementing the Everglades Construction Project (ECP), under which the state or the SFWMD will purchase lands, such as the Rotenberger property, on which stormwater treatment areas (STA), with appropriate facilities, will be designed and built to treat and improve the quality of waters coming from the EAA. The inclusion of public lands as part of the
ECP is to treat and improve the quality of waters not coming from the EAA. The SFWMD must first apply for and receive DEP permits to build these stormwater treatment facilities before the ECP can commence. Under FEFA, the SFWMD cannot levy ad valorem taxes in excess of 0.1 mills within the Okeechobee River Basin to fund the ECP. Once these STAs are completed the SFWMD must allow these areas to be used by the public for recreation, unless the SFWMD governing board can show that recreational use of the STAs are incompatible with the restoration goal of the ECP.

Concerning the improvement and restoration of the Everglades water supply, the SFWMD will use the stormwater treatment areas and facilities to increase the quantity of water in the Everglades ecosystem. The SFWMD must coordinate its water supply program with the federal government and along with the DEP push for amendments to the federal restoration program.

Concerning the research and monitoring of the Everglades, the DEP and SFWMD will head a research and monitoring program to generate water quality data for the Everglades, and to evaluate the effectiveness of BMPs and STAs in reducing the levels of phosphorus in the Everglades and in the EAA canals. The DEP will use the data generated to propose phosphorus criterion for the Everglades and the EAA canals, to evaluate existing water quality standards, and to identify new standards and phosphorus Total Maximum Daily Load (TMDL). The DEP and SFWMD will then use these water quality standards to promote and implement BMPs in the EAA.

The monitoring and controlling of exotic species is the exclusive duty of the SFWMD. FEFA requires that the SFWMD establish a biological monitoring network throughout the Everglades and perform a survey of exotic species at least every two years. The SFWMD is also required to coordinate with federal, state, or other governmental entities the control of the expansion of and removal of these exotic species.

It is also the exclusive duty of the SFWMD to assess and collect agricultural privilege taxes on agricultural land in the EAA and in "the C-139 basin" (the name of the actual basin), for the 
privilege, granted by the SFWMD, of using these lands for agricultural purposes. The SFWMD may also levy a special assessment on all areas that benefit from the STAs. All money generated by these taxes and special assessment will be used to fund the SFWMDs enforcement and implementation of FEFA.

For more information on FEFA, including state acquisition of land, and the criteria for the agricultural privilege taxes on agricultural land in the EAA and in the C-139 basin, please contact the DEP or the SFWMD.

\section{Source}

Chapter 373, Florida Statutes, Section 373.4592

\section{Acknowledgments}

The authors are indebted to the personnel of both state and federal agencies who provided their time and advice in the preparation of this handbook. The authors are especially indebted to Richard Budell of the Office of Agricultural Water Policy of the Florida Department of Agriculture and Consumer Services for providing funds for the development of this publication. 